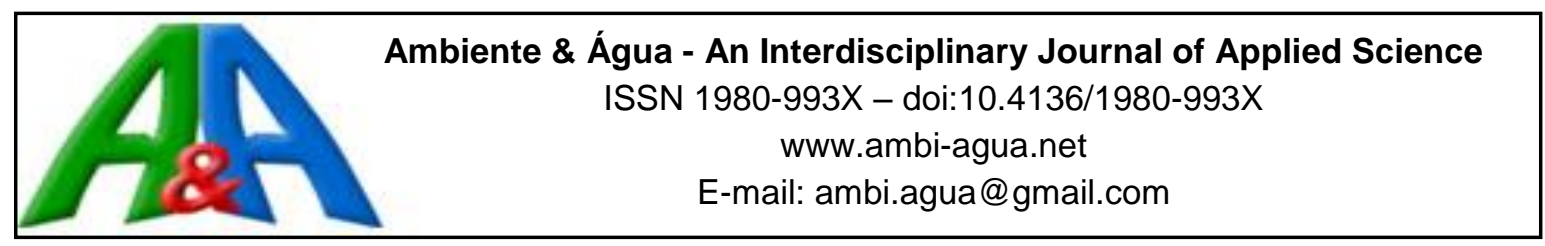

\title{
Segregation of solid waste from a fish-processing industry: a sustainable action
}

\author{
ARTICLES doi:10.4136/ambi-agua.2155
}

Received: 07 Jul. 2017; Accepted: 17 Jan. 2018

\author{
Yeda dos Santos Silva ${ }^{1}$; Liliana Pena Naval ${ }^{2 *}$ \\ ${ }^{1}$ Universidade Federal do Tocantins (UFT), Palmas, TO, Brasil \\ Programa de Pós-Graduação em Ciências do Ambiente. E-mail: enga.yedasilva@gmail.com \\ ${ }^{2}$ Universidade Federal do Tocantins (UFT), Palmas, TO, Brasil \\ Departamento de Engenharia Ambiental.E-mail: liliana@uft.edu.br \\ *Corresponding author
}

\begin{abstract}
Segregation techniques represent a sustainable alternative to minimize wastes of raw material in processing industries. This study considered the premise; its purpose was to use segregation techniques to determine the theoretical removal rate of solid compounds present in processing effluents, in order to support the sustainable development of the fish industry. The removal rates obtained for different treatments were evaluated for the parameters: total solids, organic matter and oils and greases, and the efficiency of the segregation of the effluent streams in the different stages of fish processing was evaluated through descriptive statistical analysis. The segregation recovered from $31 \%$ to $70 \%$ of total solids; from $15 \%$ to $97.50 \%$ of organic matter, and from $10 \%$ to $63 \%$ of oils and greases. These results indicates that the raw material can be used in new products, leading to reduced final-effluent concentration.
\end{abstract}

Keywords: effluent streams, fish industry, separation processes.

\section{Segregação dos resíduos sólidos na indústria processadora de pescado: uma ação sustentável}

\section{RESUMO}

A segregação é uma alternativa para redução do desperdício de matéria-prima durante o processamento do pescado, uma vez que removem das correntes de efluentes, os resíduos sólidos. Considerando-se a premissa, objetivou-se neste estudo, determinar a taxa de remoção teórica de compostos sólidos presentes em efluentes do processamento, empregando técnicas de segregação, como ação voltada para o desenvolvimento sustentável da indústria do pescado. Foram avaliadas taxas de remoção alcançadas, por diferentes tratamentos, para os parâmetros: sólidos totais, matéria orgânica e óleos e graxas, e verificada a eficiência da segregação das correntes de efluente, nas diferentes etapas do processamento do pescado, por meio de análise estatística descritiva. A segregação recuperou de $31 \%$ a $70 \%$ de sólidos totais; de $15 \%$ a 97,50\% de matéria orgânica, e de $10 \%$ a $63 \%$ de óleos e graxas, que poderão ser empregados como matéria prima para novos produtos, permitindo minimizar a concentração do efluente final.

Palavras-chave: correntes de efluente, indústria do pescado, processos de separação. 


\section{INTRODUCTION}

Food waste is a current reality, from initial processing through distribution to the final consumer, part of the raw material that reaches the food-processing industries is wasted. This factor contributes to the generation of liquid and solid waste (ONU, 2012), which reduces food availability and increases the polluting potential of the food industry. The fish-processing industry is considered to be one of the industries that generate waste with maximum load (Chowdhury et al., 2010; Cristovão et al., 2012; 2015).

The effluent generated during the processing of this product includes soluble, colloidal and particulate forms of organic contaminants (Chowdhury et al., 2010), including proteins, nutrients, oils and greases (Muthukumaran and Baskaran, 2013). The main solid waste produced consists of scales, meat, bones, cartilage and viscera (Anh et al., 2011). In processing, the disposal of these residues is between 50 and $70 \%$ of the processed fish Hernández et al., 2013; Feltes et al., 2010, Herpandi et al., 2011; Monteiro, 2013; Rustad et al., 2011; Silva et al., 2014). Of this volume of generated waste, approximately half is equivalent to organic materials (Bugalo et al., 2012), and lacks a suitable site for disposal (Morais et al., 2013). However, due to the high organic load, the potential pollutant of the final effluent is high, and should be considered (Cosmann et al., 2009; Hernández et al., 2013; Bugalo et al., 2012).

However, the search for sustainability generates goals such as the reduction of waste and the search for an increase in the efficiency of the production chain (Love et al., 2015; ONU, 2012), food availability and natural resources. Also, cleaner production, such as reuse, recycling, and other green technologies is encouraged instead of using the disposal and the endof-pipe treatment for waste management (Wu et al., 2013). This necessitates the search for alternatives applicable to food processing, which reduce the volume of the waste generated, as well as economic valuation for the by-products produced (Lago, 2015; Lopes et al., 2015; FAO, 2014).

In this scenario, segregation presents itself as a management option for the waste generated, and can be applied during the processing of the food or later, in the pre-treatment phase, before the processing effluent comes into contact with the effluent generated in the pretreatment phase, in order to reduce the risk of contamination, minimize the effluent flow, and reduce the cost of treatment and final disposal of the waste (Johanson, 2014; Alonso et al., 2010; Lopes et al., 2015; Mittal, 2006). Segregation is accomplished by adopting several techniques including: decantation, sieving, and filtration, which are unitary operations and can be used to recover part of the solid waste present in the effluent, the presence of which increases the pollutant load and requires more complexes treatments (Bezama et al., 2012).

The segregation depends on the characteristics of the constituent material. Thus, for example, different operations are required when the sedimentation, sedimentation capacity and density difference of the material are preponderant, so that the process takes place efficiently. For sieving and filtration, which use the same principle of particle separation, one should consider the size of the material to be separated (Johanson, 2014; Sutherland, 2011; 2013). It is necessary to study the fish production process and the effluent generated in the different steps. The implementation of segregation depends on the type and volume of effluent produced and the chief generating points. This study analyzed the theoretical efficiency of segregation applied to the different streams of effluents produced in a fish warehouse to reduce solids, organic matter and oils and greases, in order to support the sustainable development for the fishprocessing industry. 


\section{MATERIALS AND METHODS}

\subsection{Processing of raw material}

The study was carried out in a fish warehouse located in the northern region of Brazil, which processes $1687.50 \mathrm{~kg} / \mathrm{month}$ of fish. The species processed were Colossoma macropomumi (tambaqui), Brycon cephalus (matrinxã), Pseudoplatysto macorruscans (pintado) and Leporinus freiderici (piau). The raw material was processed through evisceration and cooling in four steps: initial (I); Evisceration (II) cooling (III) and global (IV) (Figure 1).
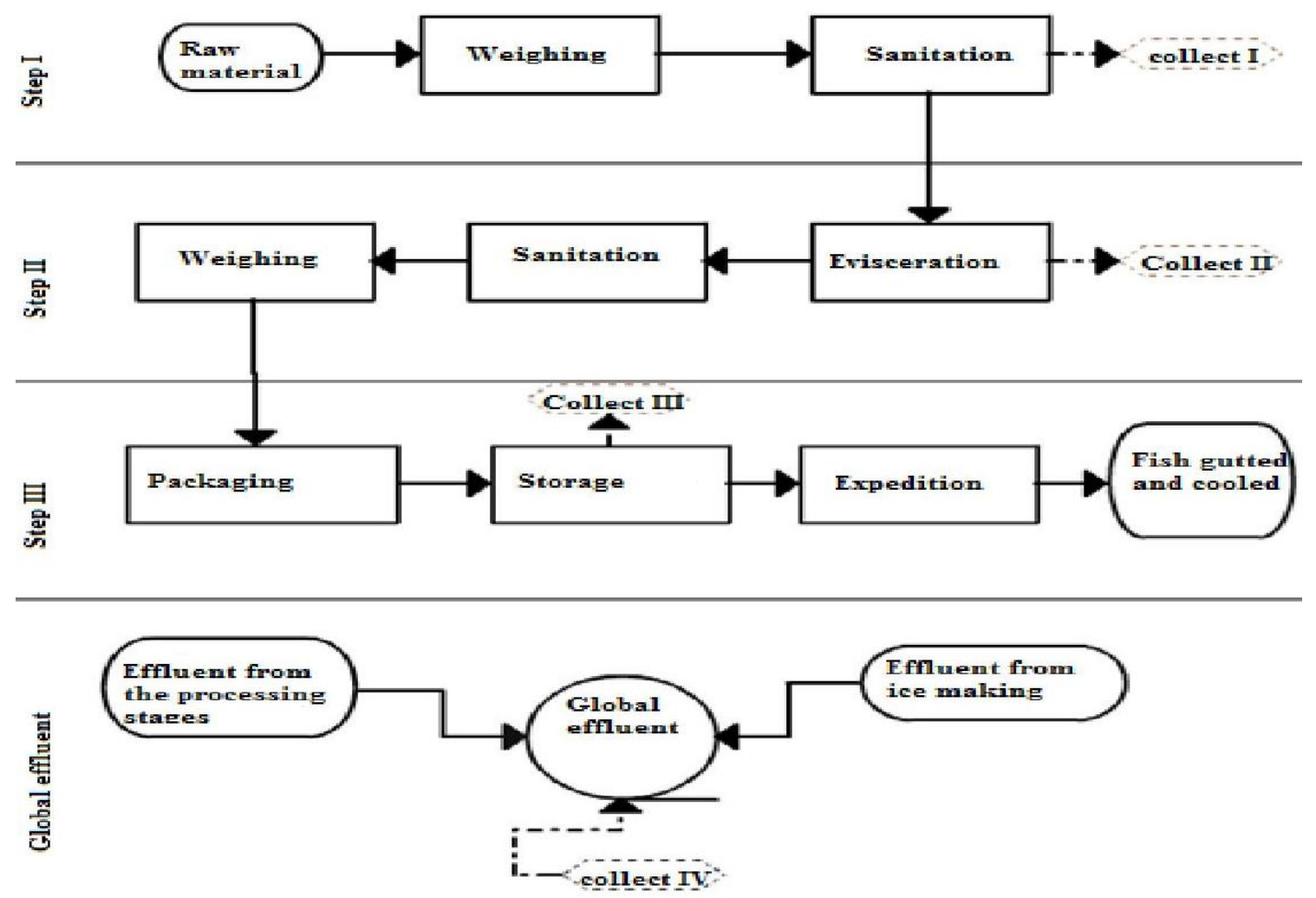

Figure 1. Fish processing in the refrigerator under study with indication of collection points of effluent samples for physical and chemical characterization.

Step I was configured for receiving, weighing, sanitizing and transporting the raw material to the subsequent step, the processing. Step I was therefore characterized by the generation of liquid effluent with the presence of pieces of fish, oils and greases. Step II was evisceration, which employs a cutting or abdominal incision table and subsequent evisceration. The fish was placed on the evisceration table, the viscera was manually removed, the product weighed, cleaned, stored and subsequent routed to refrigeration. This stage is characterized by the generation of liquid effluent with pieces of fish, oils and greases, viscera, and blood.

Step III, the cooling room, is the storage location for the product and the waste. The product was conditioned and cooled in monoblocs until distribution to market and the waste goes to the treatment plant. This step was characterized by the washing of the monoblocs, with the generation of liquid effluent accompanied by blood and residues of the material used in the cleaning of the place. Step IV corresponds to the effluent created during fish processing and monobloc washing.

\subsection{Sampling points, effluent characterization and evaluation of effluent segregation}

Effluent samples were collected at the following points: I (Initial step), after the washing cylinder; II (Processing step), after the fish evisceration table; III (Cooling step); and IV, after 
packing the product in refrigerated space monoblocs. The samples were taken at the effluent junction site (from processing and administrative area).

The analysis of the effluent was carried out as follows: total solids (ST) Ref. 2540-G Total, fixed, and volatile solids in solid and semisolid samples), biochemical oxygen demand (BOD), technique Ref. 5210 B. 5-Day BOD Test), chemical oxygen demand (COD) Ref. 5220 Closed reflux titrimetal method), and oils and greases (Ref. 5520-B Partition gravimetric method). The analyses were performed as described in the Standard methods for the examination of water and wastewater (APHA, 2005).

\subsection{The segregation of effluent streams}

In order to determine the rate of removal of the pollutants from the application of segregation in the effluent streams of each of the processing stages, the percentages of removal were determined for the studied compounds (total solids, organic matter, and oils and greases) obtained theoretically when employed in different unit operations and processes, namely:

- the percentage of theoretical removal for the separation of total solids was determined by the following techniques: screening; screen combined with filter and catch basin; screen, filter and catch basin with removal; screening with microfiltration, ultrafiltration, nanofiltration and reverse osmosis; flotation by dissolved air.

- the following techniques were used to determine the segregation of organic matter: screens; rotating filter; rotary sieve; ultrafiltration; prefiltration conjugated to nanofiltration.

- for the segregation of oils and greases, the membrane filtration processes associated with electrocoagulation were studied, specified by dynamic membrane and electrocoagulation, ceramic and electrocoagulation membrane, ceramic membrane, and dynamic membrane.

To determine the efficiency of the application of the segregation, descriptive statistical analysis was used, adopting the calculation of summary measures, taking into account the nature of the variables involved. For the inferential analysis of the results, parametric tests were used, taking into account the nature of the distributions of the values or the variability of the measurements made. This was accomplished using the Microsoft Office Excel 2007 statistical package.

\section{RESULTS AND DISCUSSION}

For the characterization of the effluent from Steps I, II, III and IV of the fish processing, the total solid parameters were analyzed, adopting the parameters: total solids, organic matter $\left(\mathrm{BOD}_{5,20}\right.$, and COD) and oils and greases. For the total solids (Figure 2a) the following average concentrations were found: $1740 \mathrm{~g} \mathrm{~L}^{-1}$ (Step I); $2714 \mathrm{~g} \mathrm{~L}^{-1}$ (Step II); $444.1 \mathrm{~g} \mathrm{~L}^{-1}$ (Step III), and $2094 \mathrm{~g} \mathrm{~L}^{-1}$ (Step IV). The concentrations were similar to those found in other studies (Chowdhury et al., 2010; Garde, 2011). They presented the typical characteristics of the processing in the industry, whose final product is only gutted fish, not filleting, or preserving, for example, that increase solids in effluents.

Using the COD test, the organic matter showed a mean concentration of $1446 \mathrm{~g} \mathrm{~L}^{-1}$ in Stage I, $1811 \mathrm{~g} \mathrm{~L}^{-1}$ in Stage II, $167.6 \mathrm{~g} \mathrm{~L}^{-1}$ in Stage III and $1592 \mathrm{~g} \mathrm{~L}^{-1}$ in Stage IV (Figure $2 \mathrm{~b})$. A high content of organic matter was found in the steps that correspond to the processing itself and in the global effluent, due to the added load which originated in the processing. This is similar to the findings of other studies (Alexandre et al., 2014; Cristovão et al., 2012; 2015; Chowdhury et al., 2010; Garde, 2011; Anh, 2011; Queiroz et al., 2013).

When analyzing the BOD, the results were compatible with those obtained in the COD analysis and the concentrations were close to those obtained in other fish processing industries (Alexandre et al., 2014; Cristovão et al., 2012; 2015; Chowdhury et al., 2010; Garde, 2011; Anh, 2011; Queiroz et al., 2013). The mean BOD concentrations of $699.1 \mathrm{~g} \mathrm{~L}^{-1}$ in Step I; 
$908 \mathrm{~g} \mathrm{~L}^{-1}$ in Step II; $80.3 \mathrm{~g} \mathrm{~L}^{-1}$, in Step III and $742.5 \mathrm{~g} \mathrm{~L}^{-1}$ in Step IV were found in this study (Figure 2c). The highest concentration of organic matter in Step II was associated with evisceration and hygiene activities, which added solid waste to the effluent collection network, such as viscera, the residue most generated in the warehouse studied, besides blood and pieces of the fish, increasing the biodegradability of the effluent. It is observed that the reduction of the organic matter content is primordial, indicative of the necessity of the segregation of this effluent.

For the oils and greases, a concentration of $0.172 \mathrm{~g} \mathrm{~L}^{-1}$ was obtained in Stage I, $0.837 \mathrm{~g} \mathrm{~L}^{-1}$ in Stage II, $0.0316 \mathrm{~g} \mathrm{~L}^{-1}$ in Stage III and $0.701 \mathrm{~g} \mathrm{~L}^{-1}$ in Stage IV (Figure 2d). All steps studied presented upper and lower limits in relation to the quality standard recommended by the legislation CONAMA Resolution 357/2005 and complementary 430/2011 (CONAMA, 2006; 2011). As expected, Step II presents a higher concentration among the other stages studied due to the characteristics of the residues generated in this as a result of evisceration. This parameter differs greatly from industry to industry, since those that process preserves add oil to the product, so these data may be divergent from study to study, such as those performed by Mosquera-Corral et al. (2001), Cristovão et al. (2012; 2015), whose concentrations were between $156 \mathrm{~g} \mathrm{~L}^{-1}$ and $2841 \mathrm{~g} \mathrm{~L}^{-1}$ of oils and greases.

a $\mathrm{b}$

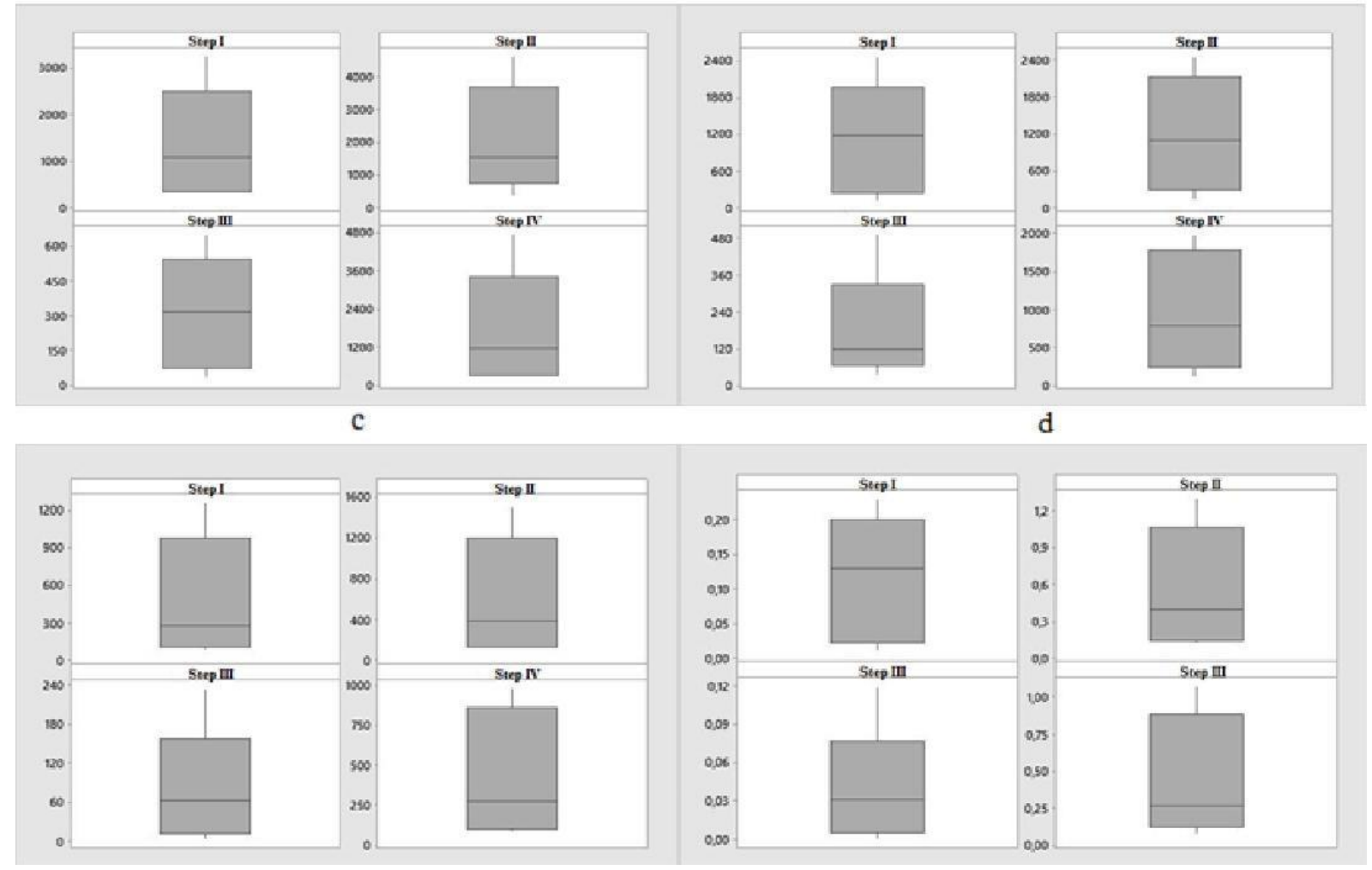

Figure 2. Concentration of total solids (a), Chemical demand for oxygen (b), biochemical oxygen demand (c), and oils and greases (d) found in the effluent generated during fish processing.

Based on the characterization of the effluent generated in the fish processing industry, a study can determine the concentrations of the parameters of interest. When applied to the segregation of effluent streams, this would aid in verifying the efficiency in reducing the concentration of these in the final effluent and in evaluating the possibility of recovery of coproducts. This is especially important because the concentration of pollutants in effluent is equivalent to the concentration of final waste from the processing industry, even for different raw materials such as fish, seafood and crustaceans (Alexandre et al., 2014; Anh et al., 2011). 
The implementation of technical segregation minimizes the final concentration of the pollutant, facilitating the operations involved in the treatment and also allowing the use of co-products, as previously mentioned. The theoretical percentages of removal obtained from the use of different segregation techniques for the studied compounds (total solids, organic matter, oils and greases) (Table 1) were used in the processing steps (I, III, II and IV) of the industry under study.

Table 1. Segregation techniques and percentages of removal achieved for the compounds studied.

\begin{tabular}{|c|c|c|}
\hline Technician employed & $\begin{array}{c}\text { Theoretical } \\
\text { adopted }\end{array}$ & References \\
\hline \multicolumn{3}{|c|}{ Total Solids (\%) } \\
\hline Screen & $31-60$ & Bezama et al. (2012); Almandoz et al. (2015) \\
\hline Screen combined with filter and catch basin & $40-70$ & FAO (2014) \\
\hline $\begin{array}{l}\text { Screening combined with microfiltration, } \\
\text { ultrafiltration, nanofiltration and reverse } \\
\text { osmosis }\end{array}$ & 100 & Gebreyohannes et al. (2016) \\
\hline Dissolved air flotation & $80-90$ & Colic et al. (2007) \\
\hline \multicolumn{3}{|c|}{ Organic matter (COD and BOD) } \\
\hline Screens & $25-60$ & Mittal (2006) \\
\hline Rotary filter & 15 & Cowi (2008) \\
\hline Rotary Sieve & 25 & Cowi (2008) \\
\hline Nanofiltration conjugated pre-filtration & 56 & Gebreyohannes et al. (2016) \\
\hline Ultrafiltration & 36 & Gebreyohannes et al. (2016) \\
\hline Nanofiltration & $60-80$ & Gebreyohannes et al. (2016) \\
\hline Dissolved air flotation & $30-90$ & $\begin{array}{l}\text { Mittall, 2006; Bustillo-Lecompte e Mehrvar } \\
\text { (2015) }\end{array}$ \\
\hline Coagulation-flotation & 90 & Lefebvre e Moletta (2006) \\
\hline Reverse osmosis & 97.5 & Gebreyohannes et al. (2016) \\
\hline \multicolumn{3}{|c|}{ Oils and greases } \\
\hline $\begin{array}{l}\text { Membrane filtration associated with } \\
\text { electrocoagulation }\end{array}$ & 65 & Yang et al. (2015) \\
\hline Ceramic membrane and electrocoagulation & 50 & Yang et al. (2015) \\
\hline Ceramic membrane & 2 & Yang et al. (2015) \\
\hline Dynamic membrane & 10 & Yang et al. (2015) \\
\hline Floating & $37-63$ & Colic et al. (2007) \\
\hline Screen & $10-20$ & Colic et al. (2007) \\
\hline
\end{tabular}

The results when using the theoretical percentages of removal, related to the total solids found in the effluents from Steps I, II, III and IV according to the segregation techniques adopted. When simplified techniques are used, the reduction is from 25 to $60 \%$ (Figure 3a and b). However, reductions of up to $90 \%$ are achieved when the techniques are associated (Figure 3c).

For the techniques that considered the removal of total solids, using screening, the removal achieved was $31 \%$ (Figure 3a); the screen $40 \%$ to $60 \%$ (Figure 3b); filter screen and catch basin $40 \%$ to $70 \%$ (Figure 3c), and $80 \%$ to $90 \%$ dissolved air flotation (FAD) (Figure 3d).

For removal of organic matter, the highest theoretical percentages were associated with segregation techniques that operate through nanofiltration, dissolved air flotation, coagulationflotation and reverse osmosis (Figure 4). These segregation techniques were able to remove up to $97.50 \%$ of the organic matter (Figure 4), that results in a quality effluent to be directly released into a water body, or to be reused or recycled in the processing, according to Brazilian legislation in force (Resolution CONAMA 430/2011 (CONAMA, 2011) and Resolution $54 / 2005$ of the CNRH (2006). If the effluent from segregation is treated, a simplified system 
will suffice. When the less efficient techniques are adopted, such as screens, it is still possible to achieve a 25 to $60 \%$ reduction, which is important, when the compound is to be minimized, as organic matter considered as one of the big problems for the treatment of effluents.

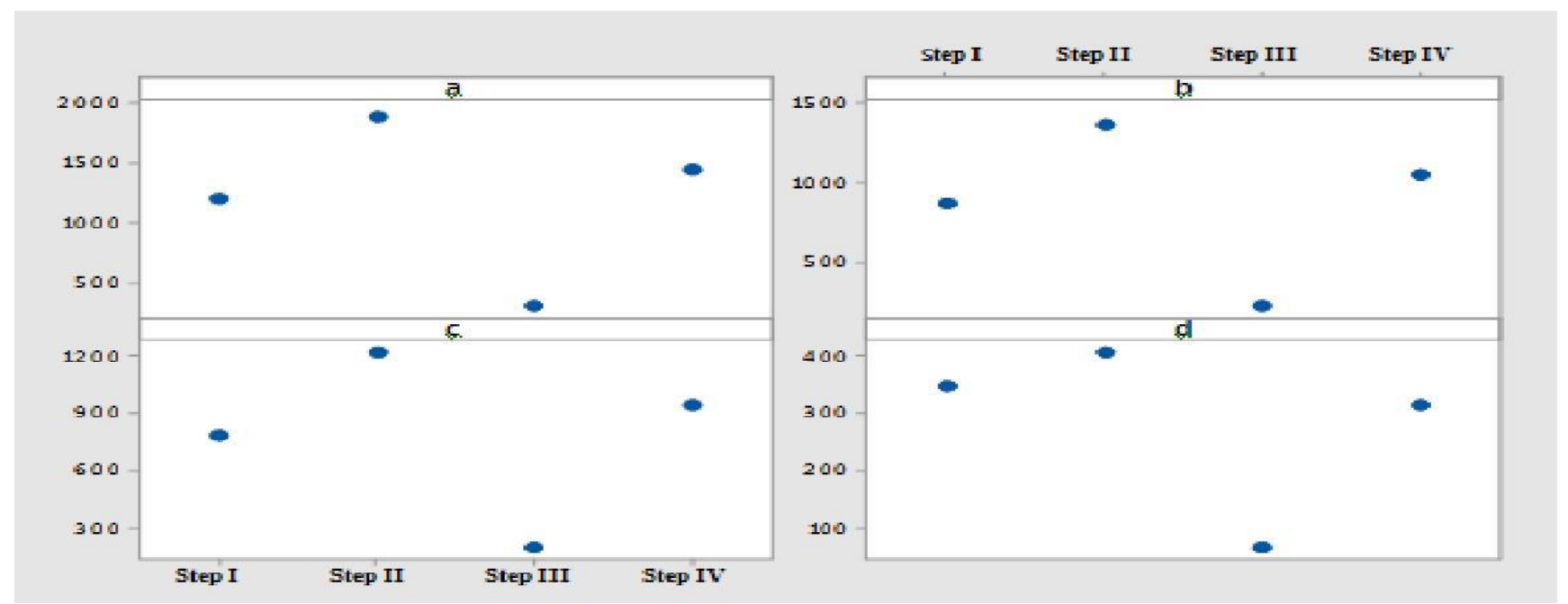

Figure 3. Estimation of total solids concentration in the processing effluent after application of segregation techniques.

Legends: (a) Screening; (b) Screen; (c) Screen combined with filter and catch basin; (d) Dissolved air flotation (DAF).

In general, the rate of removal of organic matter obtained when using screens was $25 \%$ to $60 \%$ (Figure $4 \mathrm{a}$ ); rotary filters reached $15 \%$ (Figure $4 \mathrm{~b}$ ); rotating sieve reached $25 \%$ (Figure $4 \mathrm{c}$ ); nanofiltration conjugated prefiltration reached 56\% (Figure 4d); ultrafiltration reached $30 \%$ to $36 \%$ (Figure 4e); nanofiltration reached $60 \%$ to $80 \%$ (Figure 4f); dissolved air flotation reached $30 \%$ to $90 \%$ (Figure $4 \mathrm{~g}$ ); coagulation-flotation reached $90 \%$ (Figure $4 \mathrm{~h}$ ), and reverse osmosis $97.50 \%$ (Figure 4i).

The removal rates obtained for oils and greases, when theoretical removal is applied: membrane filtration associated with electrocoagulation, 65\% (Figure 5ba); Ceramic membrane and electrocoagulation, 50\% (Figure 5b); Ceramic membrane, 2\% (Figure 5c); dynamic membrane, $10 \%$ (Figure 5d); flotation, 37\% and 63\% (Figure 5e); and screen, $10 \%$ to $20 \%$ (Figure 5f).

Oils and greases must be removed from fish-processing effluents, because they interfere with oxygen transfer, and cause operational problems in treatment systems (Alexandre et al., 2014); but primary treatments are sufficient to remove this contaminant, at least in part (Muthukumaran and Baskaran, 2013). In this study, when used at the theoretical removal rate achieved by the segregation techniques studied (Figure 5), it was possible to reduce up to 65\% of the initial concentration when membrane filtration associated with electrocoagulation was adopted (Figure 5a).

Flotation reached from $37 \%$ to $63 \%$ removal for the parameter (Figure 5e). Due to the importance of this parameter, even the lowest rates of reduction contribute to both effluent treatment and disposal. It is also important to consider the possibility that this compound can be used to produce biofuels (Jayasinghe and Hawboldt, 2012; Alonso et al., 2010; Adeoti and Hawboldt, 2014). 


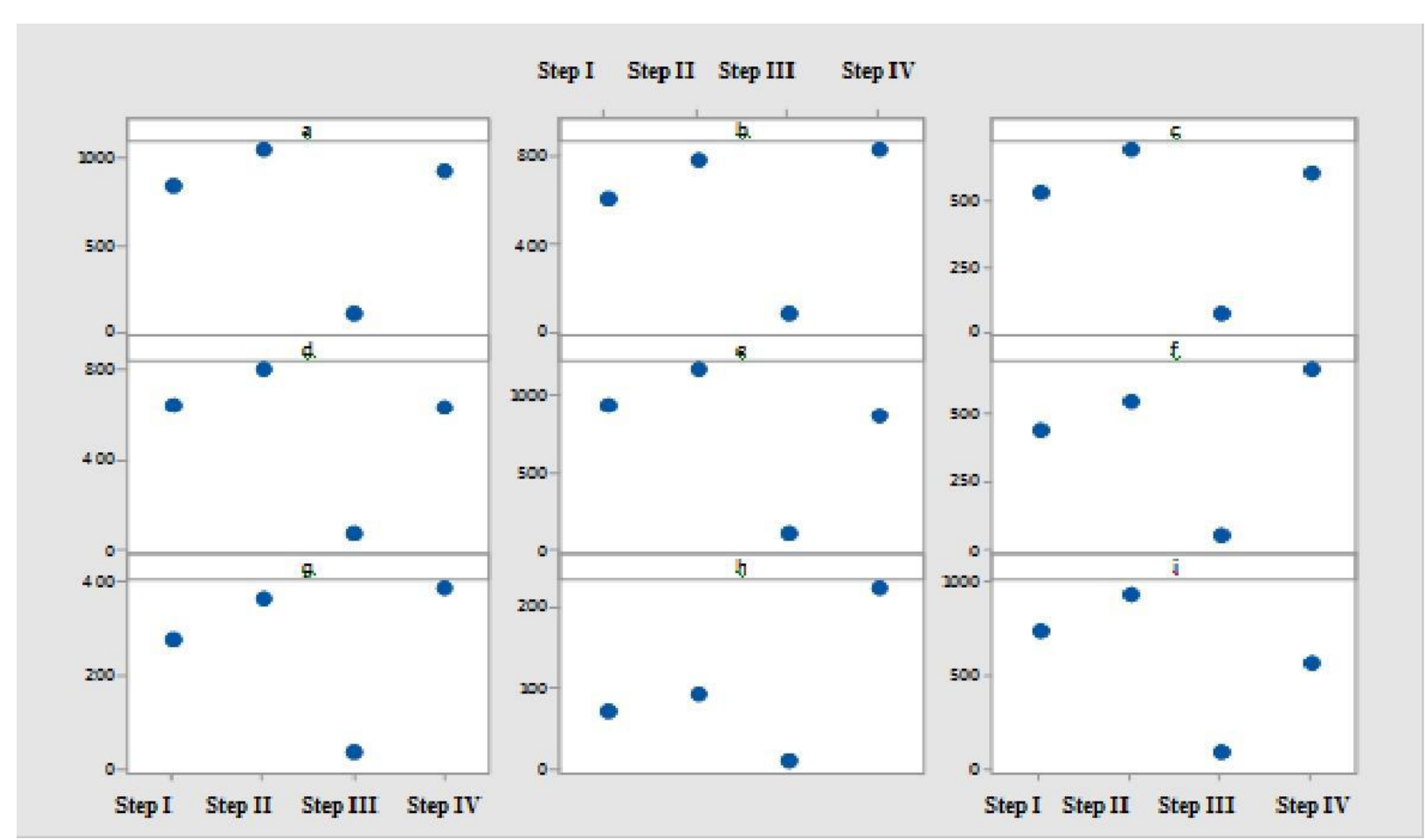

Figure 4. Theoretical removal of organic matter from the studied effluent in concentrations ( $\mathrm{g} L-1)$ of (a) Biochemical Oxygen Demand and (b) Chemical Oxygen Demand of effluent from segregation.

Legend: (a) Screens; (b) Rotary filter; (c) Rotary sieve; (d) Nanofiltration conjugated prefiltration; (e), Ultrafiltration; (f) Nanofiltration; (g) Dissolved air flotation; (h) Coagulation-flotation; (i) Reverse Osmosis.

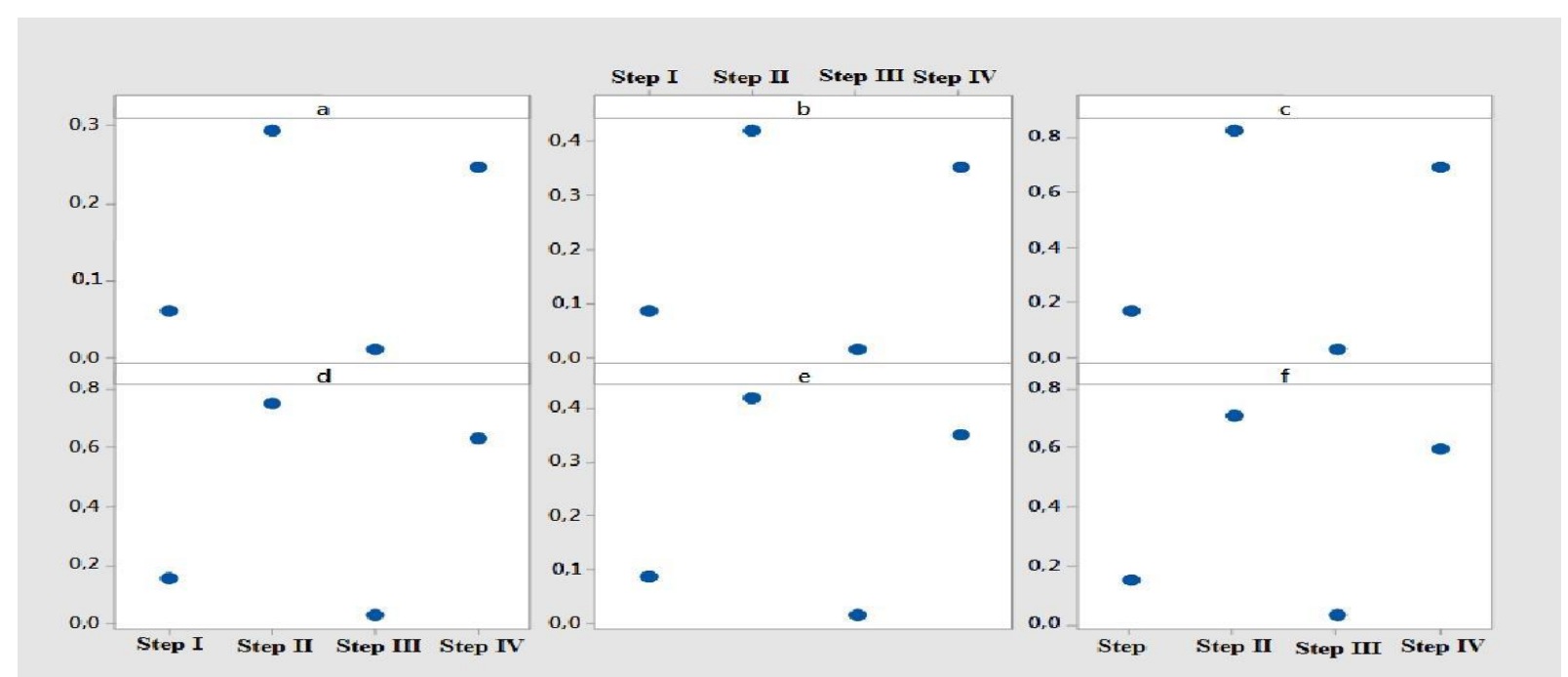

Figure 5. Oils and greases in $\mathrm{mg} / \mathrm{L}$ per step after application of the rates of removal by segregation technique present in the effluent in fish-processing industry.

Legend: (a) Membrane filtration associated with electrocoagulation; (B) Ceramic membrane and electrocoagulation; (C) Ceramic membrane; (D) Dynamic membrane; (E) Flotation; (F) Screen.

Analyzing the results, segregation proved to be an efficient technique to minimize concentrations of the studied compounds: total solids, organic matter and oils and greases (Table 2). However, it does not exempt the final treatment effluent. The COD/BOD ratio below 2.5 indicates biodegradable matter, so there is an indication that it requires treatment for stabilization. 
The segregation techniques have been shown to be effective in keeping waste out of the drain and reducing effluent treatment costs (Watson, 2003), as well as to be technologies used for the fish processing residues in order to foster development of the socioeconomic and environmental sustainability of the industry (Anbe, 2011). Studies of the valuation of byproducts of fish processing conclude that the segregated material can be used in the creation of new products, with low raw material and production costs, increasing industry profit and reducing environmental impact (Arvanitoyannis and Kassaveti, 2008; Monteiro, 2013; Silva et al., 2015); with this favors the generation of new jobs.

The alternatives of reuse of fish-processing residues are available for animal and human consumption, which can contribute to the establishment of a fishing sector committed to environmental issues (Alonso et al, 2010). It is also possible to use the residues for the production of collagen and antioxidant isolation for cosmetics, biogas/biodiesel, fertilizers, dietary applications (chitosan), food packaging (gelatin), enzyme isolation (proteases) (Arvanitoyannis and Kassaveti, 2008; Oliveira et al., 2015) and fishmeal, as the most common reuse alternative (Jayasinghe and Hawboldt, 2012; Jayasinghe and Hawboldt, 2013; Adeoti and Hawboldt, 2014; Lin and Li, 2009). The purpose of this improvement in the production process is to improve the performance of the market in response to the demand for new food products or as required by governing legislation (Bar, 2015). 
Table 2. Methods of segregation employed in-fish processing industry for the removal of total solids, organic matter and oils and greases, and maximum efficiency when applied in the following processing Steps: I (Initial stage) after the washing cylinder; II (Processing stage), after the fish-evisceration table; III (Cooling stage), after packing the product in monoblocs in refrigerated space; and IV (Processing effluent stage and administrative area).

\begin{tabular}{|c|c|c|c|c|c|c|c|}
\hline \multicolumn{8}{|c|}{ Total Solids } \\
\hline Techniques & Theoretical removal & \multicolumn{2}{|c|}{$[\mathrm{C}]$ inicial $(\mathrm{mg} / \mathrm{L})$} & $\mathrm{I}(\mathrm{mg} / \mathrm{L})$ & II $(\mathrm{mg} / \mathrm{L})$ & III (mg/L) & IV $(\mathrm{mg} / \mathrm{L})$ \\
\hline Screening & $31 \%$ & \multicolumn{2}{|c|}{1740} & 1201 & 1873 & 306 & 1445 \\
\hline Screen & $40 \%$ a $60 \%$ & \multicolumn{2}{|c|}{1740} & 870 & 1357 & 222 & 1047 \\
\hline Screen combined with filter and catch basin & $40 \%$ a $70 \%$ & \multicolumn{2}{|c|}{1740} & 783 & 1221 & 200 & 942 \\
\hline Dissolved air flotation (FAD) & $80 \%$ a $90 \%$ & \multicolumn{2}{|c|}{1740} & 348 & 407 & 67 & 314 \\
\hline \multicolumn{8}{|c|}{ Organic matter } \\
\hline \multirow[t]{2}{*}{ Techniques } & Theoretical removal & \multicolumn{2}{|c|}{ [C]inicial } & $\mathrm{I}(\mathrm{mg} / \mathrm{L})$ & II $(\mathrm{mg} / \mathrm{L})$ & III $(\mathrm{mg} / \mathrm{L})$ & $\mathrm{IV}(\mathrm{mg} / \mathrm{L})$ \\
\hline & & \multicolumn{2}{|l|}{ DQO (mg/L) } & & & & \\
\hline Screens & $25 \%$ a $60 \%$ & & 699 & 8314 & 1041,3 & 96,37 & 915,4 \\
\hline Rotary filter & $15 \%$ & & 699.1 & 594.2 & 771.8 & 68.2 & $820 . .6$ \\
\hline Rotary Sieve & $25 \%$ & & 699.1 & 524.3 & 681 & 60.22 & 594 \\
\hline Nanofiltration conjugated prefiltration & $56 \%$ & 1446 & & 636.2 & 796.8 & 73.74 & 628.7 \\
\hline Ultrafiltration & $30 \%$ a $36 \%$ & 1446 & & 925.44 & 1159 & 107.2 & 859.7 \\
\hline Nanofiltration & $60 \%$ a $80 \%$ & 1446 & & 433.8 & 543.3 & 50.3 & 658.0 \\
\hline Dissolved air flotation & $30 \%$ a $90 \%$ & & 699.1 & 279.6 & 363.2 & 32.12 & 387.3 \\
\hline Coagulation-flotation & $90 \%$ & & 699.1 & 69.9 & 90.8 & 8.03 & 222.7 \\
\hline Osmose Reversa & $97,50 \%$ & 1446 & & 36 & 35 & 4 & 40 \\
\hline \multicolumn{8}{|c|}{ Oils and greases } \\
\hline Techniques & Theoretical removal & \multicolumn{2}{|c|}{ [C]inicial } & $\mathrm{I}(\mathrm{mg} / \mathrm{L})$ & II (mg/L) & III (mg/L) & $\mathrm{IV}(\mathrm{mg} / \mathrm{L})$ \\
\hline Membrane filtration associated with electrocoagulation & $65 \%$ & \multicolumn{2}{|c|}{0.17} & 0.06 & 0.29 & 0.001 & 0.25 \\
\hline Ceramic membrane and electrocoagulation & $50 \%$ & \multicolumn{2}{|c|}{0.17} & 0.09 & 0.42 & 0.02 & 0.35 \\
\hline Ceramic membrane & $2 \%$ & \multicolumn{2}{|c|}{0.17} & 0.17 & 0.82 & 0.03 & 0.69 \\
\hline Dynamic membrane & $10 \%$ & \multicolumn{2}{|c|}{0.17} & 0.15 & 0.75 & 0.03 & 0.63 \\
\hline Floating & $37 \%$ e $63 \%$ & \multicolumn{2}{|c|}{0.17} & 0.09 & 0.42 & 0.02 & 0.35 \\
\hline Screen & $10 \%$ a $20 \%$ & \multicolumn{2}{|c|}{0.17} & 0.15 & 0.71 & 0.03 & 0.60 \\
\hline
\end{tabular}




\section{CONCLUSION}

The segregation techniques studied showed that, for the effluent under study, higher rates of removal of solids, organic matter and oils and greases were reached when conjugated processes were adopted. The result is a final effluent with less polluting potential, thus requiring a more-simplified treatment.

Segregation of total solids, organic matter and oils and greases showed a better result in Step II (evisceration step) as a function of the solid waste load, such as pieces of fish, viscera and blood generated during processing.

Due to the low load of total solids, organic matter and oils and greases of Stage III (monobloc wash), the implementation of segregation techniques would result in an effluent in accordance with Brazilian legislation in force.

The introduction of segregation processes in the effluent streams not only allows the production of a better final effluent, but also the reduction of by-product loss.

\section{ACKNOWLEDGEMENTS}

The authors are grateful to the Brazilian governmental agency National Council for Scientific and Technological Development $(\mathrm{CNPq})$ for the project funding (Process number: 407728/ 2012-0) and a scholarship (Process number: 312697/ 2014-7).

\section{REFERENCES}

ADEOTI, I. A.; HAWBOLDT, K. A review of lipid extraction from fish processing by-product for use as a biofuel. Biomass and Bioenergy, v. 63, p. 330-340, 2014. https://doi.org/10.1016/j.biombioe.2014.02.011

ALONSO, A. A. et al. Contributing to fisheries sustainability by making the best possible use of their resources: the befair initiative. Trends in food science \& technology, v. 21, n. 11, p. 569-578, 2010. https://doi.org/10.1016/j.tifs.2010.07.011

ALEXANDRE, V. M. F.; VALENTE, A. M.; CAMMAROTA, M. C.; FREIRE, D. M. G. Performance of anaerobic bioreactor treating fish-processing plant wastewater prehydrolyzed with solid enzyme pool. Renew Energy, v. 36, p. 3439-3444, 2014. https://doi.org/10.1016/j.renene.2011.05.024

ALMANDOZ, M. C.; PAGLIERO, C. L.; OCHOA, N. A.; MARCHESE, J. Composite ceramic membranes from natural aluminosilicates for microfiltration applications. Ceramics $\begin{array}{llllll}\text { International, } & \text { v. } & 41, & \text { p. } & 5621-5633, & 2015 .\end{array}$ https://doi.org/10.1016/j.ceramint.2014.12.144

ANBE, L. Prospecção de componentes bioativos em resíduos do processamento do pescado visando a sustentabilidade da cadeia produtiva. 2011. Dissertação (Mestrado) - Escola Superior de Agricultura Luiz de Queiroz, Universidade de São Paulo, Piracicaba, 2011.

ANH, P. T. et al. Towards eco-agro industrial clusters in aquatic production: the case of shrimp processing industry in Vietnam. Journal of Cleaner Production, v. 19, p. 2107-2118, 2011. https://doi.org/10.1016/j.jclepro.2011.06.002

AMERICAN PUBLIC HEALTH ASSOCIATION - APHA. Standard methods for the examination of water and wastewater. 20th ed. Washington D.C., 2005. 
ARVANITOYANNIS, I. S.; KASSAVETI, A. Fish industry waste: treatments, environmental impacts, current and potential uses. International Journal of Food Science \& Technology, v. 43, p. 726-745, 2008. https://doi.org/10.1111/j.1365-2621.2006.01513.x

BAR, E. S. A case study of obstacles and enablers for green innovation within the fish processing equipment industry. Journal of Cleaner Production, v. 90, p. 234-243, 2015. https://doi.org/10.1016/j.jclepro.2014.11.055

BEZAMA, A. et al. Evaluation of the environmental impacts of a Cleaner Production Agreement by frozen fish facilities in the Biobío Region, Chile. Journal of Cleaner Production, v. 26, p. 95-100, 2012. https://doi.org/10.1016/j.jclepro.2011.12.029

BUGALLO, P. M.; STUPAK, A.; ANDRADE, L. C.; LÓPEZ, R. T. Material flow analysis in a cooked mussel processing industry. Journal of Food Engineering, v. 113, n. 1, p. 100117, 2012. https://doi.org/10.1016/j.jfoodeng.2012.05.014

BUSTILLO-LECOMPTE, C. F.; MEHRVAR, M. Slaughterhouse wastewater characteristics, treatment, and management in the meat processing industry: A review on trends and advances. Journal of Environmental Management, v. 161, n. 15, p. 287-302, 2015. https://doi.org/10.1016/j.jenvman.2015.07.008

CHOWDHURY, P.; VIRARAGHAVAN, T.; SRINIVASAN, A. Biological treatment processes for fish processing wastewater - A review. Bioresearches Technology, v. 101, p. 439-449, 2010. https://doi.org/10.1016/j.biortech.2009.08.065

COLIC, M. et al. Case study: fish processing plant wastewater treatment. Proceedings of the Water Environment Federation, v. 2007, n. 7, p. 1-27, 2007. https://doi.org/10.2175/193864707787781557

CONSELHO NACIONAL DO MEIO AMBIENTE - CONAMA (Brasil). Resolução n 430, de 13 de maio de 2011. Dispõe sobre as condições de lançamento de efluentes, complementa e altera a Resolução n ${ }^{\circ}$ 357. Diário Oficial [da] União, Brasília, DF, n. 92, 16 maio 2011, p. 89.

CONSELHO NACIONAL DE RECURSOS HÍDRICOS - CNRH (Brasil). Resolução ${ }^{\circ} 54$, de 28 de novembro de 2005. Estabelece modalidades, diretrizes e critérios gerais para a prática de reuso direto não potável de água, e dá outras providências. Diário Oficial [da] União, Brasília, DF, 09 mar. 2006.

COSMANN, N. J.; GOMES, S. D.; ANDRADE, L.; KUMMER, A. C. B. Caracterização do efluente de processamento de pescado e desempenho da lagoa anaeróbia. In: SIMPÓSIO INTERNACIONAL SOBRE GERENCIAMENTO DE RESÍDUOS DE ANIMAIS TRATAMENTO DE DEJETOS DE ANIMAIS, 1., 11- a 13 de Março de 2009, Florianópolis, SC. Anais... Brasília: Embrapa, 2000.

COWI CONSULTING ENGINEERS AND PLANNERS AS. Cleaner production assessment in meat processing. Paris: 2008.

CRISTÓVÃO, R. O.; BOTELHO, C. M. S.; MARTINS, R. J.;E.; BOAVENTURA, R. A.;R. Fish canning industry wastewater treatment for water reuse e a case study. Journal of $\begin{array}{llllll}\text { Cleaner Production, } & \text { v. 87, } & \text { p. }\end{array}$ https://doi.org/10.1016/j.jclepro.2014.10.076 
CRISTÓVÃO, R. O.; BOTELHO, C. M. S.; MARTINS, R. J. E.; BOAVENTURA, R. A. R. Chemical and biological treatment of fish canning wastewaters. International Journal of Bioscience, Biochemistry and Bioinformatics, v.2, p. 237-242, 2012. http://dx.doi.org/10.7763/IJBBB.2012.V2.108

FOOD AND AGRICULTURE ORGANIZATION OF THE UNITED NATIONS - FAO. The State of World Fisheries and Aquaculture: opportunities and challenges. Rome, 2014. $223 \mathrm{p}$.

FELTES, M. C. M. et al. Alternativas para a agregação de valor aos resíduos da industrialização de peixe. Revista Brasileira de Engenharia Agrícola e Ambiental, v. 14, n. 6, p. 669677, 2010. https://doi.org/10.1590/S1415-43662010000600014

GARDE, J. Treatment of wastewater from a fish conservation industry: flocculation experiment and analysis. 2011. Tese (Mestrado) - Schoolof Business and Engineering, Halmstad University, 2011.

GEBREYOHANNES, A. Y.; MAZZEI, R.; GIOR, L. Trends and current practices of olive mill wastewater treatment: application of integrated membrane process and its future perspective. Separation and Purification Technology, v. 162, 2016. https://doi.org/10.1016/j.seppur.2016.02.001

HERNÁNDEZ, C. et al. Use of tuna industry waste in diets for nile tilapia, oreochromisniloticus, fingerlings: effect on digestibility and growth performance. Latinamerican Jornal of Aquatic Research, v. 41, n. 3, p. 468-478, 2013. https://doi.org/103856/vol41-issue3-fulltext-10

HERPANDI, N. H.; ROSMA, A.; WAN NADIAH, W. A. The Tuna Fishing Industry: A New Outlook on Fish Protein Hydrolysates. Comprehensive Reviews in Food Science and Food Safety, v.10, p.195-207, 2011. https://doi.org/10.1111/j.1541-4337.2011.00155.x

JAYASINGHE, P.; HAWBOLDT, K. A review of bio-oils from waste biomass: Focus on fish processing waste. Renewable and Sustainable Energy Reviews, v. 16, p.798-821, 2012. https://doi.org/10.1016/j.rser.2011.09.005

JAYASINGHE, P.; HAWBOLDT, K. Biofuels from fish processing plant effluents - waste characterization and oil extraction and quality. Sustainable Energy Technologies and Assessments, v. 4, p. 36-44, 2013. https://doi.org/10.1016/j.seta.2013.09.001

JOHANSON, K. Review of new segregation tester method by dr. Kerry Johanson, P.E. Powder technology, v. 257, , p. 1-10, 2014. https://doi.org/10.1016/j.powtec.2014.02.021

LAGO, A. M. T. Embutido tipo salsicha utilizando carne mecanicamente separada de tilápia: uma alternativa para o aproveitamento de resíduo da filetagem. 2015. 231 p. Dissertação (Mestrado em Ciência dos Alimentos) - Universidade Federal de Lavras, Lavras, 2015.

LEFEBVRE, O.; MOLETTA, R. Treatment of organic pollution in industrial saline wastewater: a literature review. Water Research, v. 40, n. 20, p. 3671-3682, 2016. https://doi.org/10.1016/j.watres.2006.08.027

LIN, C.-Y.; LI, R.-J. Engine performance and emission characteristics of marine fish-oil biodiesel produced from the discarded parts of marine fish. Fuel Processing Technology, v. 90, p. 883-888, 2009. https://doi.org/10.1016/j.fuproc.2009.04.009 
LOPES, C. et al. Valorisation of fish by-products against waste management treatments comparison of environmental impacts. Waste Management, v. 46, p. 103-112, 2015. https://doi.org/10.1016/j.wasman.2015.08.017

LOVE, D. C. et al. Wasted seafood in the United states: quantify in gloss from production to consumption and moving to Ward solutions. Global Environmental Change, v. 35, p. 16-124, 2015. https://doi.org/10.1016/j.gloenvcha.2015.08.013

MITTAL, G. S. Treatment of waste water from abattoirs before land application- a review.

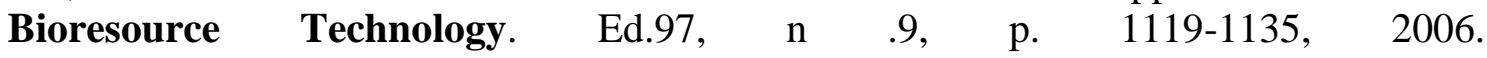
https://doi.org/10.1016/j.biortech.2004.11.021

MONTEIRO, M. L. G. Aproveitamento de resíduos de tilápia(Oreochromisniloticus) para elaboração de novos produtos com valor agregado. 2013. Tese (Doutorado em Higiene Veterinária e Processamento Tecnológico de Produtos de Origem Animal) - Universidade Federal Fluminense, Rio de Janeiro, 2013.

MORAIS, J. P. S.; LEITÃO, C. R.; FIGUEIRÊDO, M. C. B.; SAMPAIO, A. P. C.; SOUZA FILHO, E. F. M. M. S. M.; RODRIGUES, M. L. L. et al. Balanço de massa na obtenção de carne mecanicamente separada (CMS) de tilápia. Fortaleza: EMBRAPA, 2013.

MOSQUERA-CORRAL, A. et al. Simultaneous methanogenesis and denitrification of pretreated effluents from a fish canning industry. Water Research, v. 35, n. 2, p. 411418, 2001. https://doi.org/10.1016/S0043-1354(00)00288-8

MUTHUKUMARAN, S.; BASKARAN, K. Organic and nutrient reduction in a fish processing facility e A case study. International Biodeterioration \& Biodegradation. v. 85, p. 563-570, 2013. https://doi.org/10.1016/j.ibiod.2013.03.023

OLIVEIRA, I. S. D. et al. Composition of MSM from Brazilian catfish and technological properties of fish flour. Food Control, v. 50, p. 38-44, 2015. https://doi.org/10.1016/j.foodcont.2014.08.018

ORGANIZAÇÃO DAS NAÇÕES UNIDAS - ONU. Fatos sobre alimentação. Rio de Janeiro, 2012.

QUEIROZ, M. I. et al. Fish processing wastewater as a platform of the microalgal biorefineries. $\begin{array}{llllll}\text { Biosystems } & \text { Engineering, } & \text { v. 115, }\end{array}$ https://doi.org/10.1016/j.biosystemseng.2012.12.013

RUSTAD, T.; STORRO, I.; SLIZYTE, R. Possibilities for the utilisation of marine by-products. International Journal of Food Science \& Technology, v. 46, p. 2001-2014, 2011. https://doi.org/10.1111/j.1365-2621.2011.02736.x

SILVA, A. J. et al. Utilization of tilapia processing waste for the production of fish protein hydrolysate. Animal Feed Science and Technology, v. 196, n. 11, p. 96-106, 2014. https://doi.org/10.1016/j.anifeedsci.2014.06.010

SILVA, R. A.; BONNAS, D. S.; SILVA, P. F. Aproveitamento dos resíduos gerados no processamento de postas de surubim (Pseudoplatystoma corruscans) para elaboração de nuggets. Contextos da Alimentação. Revista de Comportamento, Cultura e Sociedade, v. 3, n. 2, 2015.

SUTHERLAND, K. Filter media guidelines: Selecting theright filter media. Filtration + Separation, v. 48, n. 3, p. 21-22, 2011. https://doi.org/10.1016/S0015-1882(11)70117-3 
SUTHERLAND, K. Half a century of developments in filtration - Part 3. Filtration+Separation, v. 50, n. 3, p. 23-27, 2013.

YANG, T. et al. Improving performance of dynamic membrane assisted by electrocoagulation for treatment of oily wastewater: Effect of electrolytic conditions. Desalination, v. 363, p. 134-143, 2015. https://doi.org/10.1016/j.desal.2015.01.010

WATSON, R. Trials to Reduce Water and Effluent Charges in Fish Processing. [S.1.]: The Sea Fish Industry Authority, 2003. Seafish Report N.SR541.

WU, T. Y.; MOHAMMAD, A. W.; LIM, S. L.; LIM, P. N.; HAY, J. X. W. Recent advances in the reuse of wastewaters for promoting sustainable development. In: SHARMA, S. K.; SANGHI, R. (Eds.). Wastewater Reuse and Management. Netherlands: Springer, 2013. p. 47-103. https://doi.org/10.1007/978-94-007-4942-9_3 